\title{
Antagonism of organic and inorganic activators in copper local depassivation in alkaline solutions
}

\section{E.A. Skrypnikova, ${ }^{1}$ S.A. Kaluzhina, ${ }^{* 2}$ E.V. Orlova ${ }^{3}$ and L.N. Volkova ${ }^{2}$}

${ }^{1}$ MESC Air Force Military Air Academy named after N. E. Zhukovsky and Yu. A. Gagarin, ul. Staryh bolshevikov 54a, Voronezh, 394000 Russian Federation

${ }^{2}$ Voronezh State University, Universitetskaya pl. 1, Voronezh, 394006 Russian Federation *E-mail: kaluzhina@vmail.ru

${ }^{3}$ N. N. Burdenko Voronezh State Medical Academy, Studencheskaya ul. 10, Voronezh, 394036 Russian Federation

\begin{abstract}
The local depassivation of copper in alkaline medium $(\mathrm{pH}=12)$ in the presence of organic activators (glycine, $\alpha$-alanine, $\beta$-alanine) simultaneously with inorganic ones $(\mathrm{NaCl})$ was studied. The studies were carried out in background electrolytes: $1 \cdot 10^{-2} \mathrm{M} \mathrm{NaOH}+5 \cdot 10^{-3} \mathrm{M}$ Gly, $1 \cdot 10^{-2} \mathrm{M} \mathrm{NaOH}+5 \cdot 10^{-3} \mathrm{M} \alpha$-Ala, and $1 \cdot 10^{-2} \mathrm{M} \mathrm{NaOH}+1 \cdot 10^{-2} \mathrm{M} \beta$-Ala. The concentration of the additive $(\mathrm{NaCl})$ in the working electrolyte was varied in a wide range from $1 \cdot 10^{-6}$ to $1 \cdot 10^{-1} \mathrm{M}$. It was found that $\mathrm{NaCl}$ can affect the intensity of copper local depassivation in two ways. At inorganic additive concentrations in the range of $1 \cdot 10^{-6}$ $1 \cdot 10^{-4} \mathrm{M}$, significant suppression of the depassivation process occurs, which changes to acceleration in the $\mathrm{NaCl}$ concentration range of $1 \cdot 10^{-4}-1 \cdot 10^{-1} \mathrm{M}$. An explanation of the observed effects was suggested from the viewpoint of competitive adsorption, nucleophilic substitution and complexing theories for particles present in the systems being studied.
\end{abstract}

Key words: copper, local activation, glycine, $\alpha$-alanine, $\beta$-alanine, $\mathrm{Cl}^{-}$ions.

Received: October 11, 2012

doi: $\underline{10.17675 / 2305-6894-2013-2-1-001-008}$

\section{Introduction}

Studies on the peculiarities of metal local corrosion in systems where inorganic and organic compounds are simultaneously present are very important from theoretical and practical aspects (for development of the concepts of competitive adsorption, surface and volume complexing, synergism and antagonism in the presence of corrosion activators simultaneously with inhibitors). Due to their widespread occurrence in the wastes of various plants, including food and pharmaceutical production [1], the applied importance of such systems is no less essential.

Earlier [2-4] it has been proved that microadditives of chloride ions have a protective effect on copper local depassivation caused by carboxylic acids. In order to confirm (or disprove) the possibility of similar influence of an inorganic activator on the intensity of copper local depassivation in more complex systems, special studies were carried out in alkaline solutions simultaneously containing organic activators in the form of various 
amino acid (AA) anions at fixed concentrations and an inorganic activator $\left(\mathrm{Cl}^{-}\right.$ions) in a wide range of concentrations.

\section{Experimental}

The experiments were carried out in a glass three-electrode electrolytic cell ( $V=$ $0.250 \mathrm{dm}^{3}$ ) with undivided cathode and anode areas. The working electrode (a cylinder of M1 grade copper, 99.9 mass.\% $\mathrm{Cu}$ ) was embedded in epoxy resin and had a working surface $S=7.850 \cdot 10^{-5} \mathrm{~m}^{2}$. A silver chloride electrode $(E=0.200 \mathrm{~V}$ (NHE)) was used as the reference electrode, which was connected with the working electrode through a salt bridge filled by the working electrolyte, with a Haber-Luggin capillary at the end. A platinum gauze served as the counter electrode. The potentials presented in this work were recalculated versus normal hydrogen electrode (NHE).

Alkaline solutions $(\mathrm{pH}=12)$ containing fixed concentrations of an AA (glycine (Gly), $\alpha$-alanine ( $\alpha$-Ala), or $\beta$-alanine ( $\beta$-Ala)) were chosen as the background electrolytes. All the amino acids studied were used mainly in dissociated form because their anions cause the most intense local corrosion of copper. Taking the above statements into account, the background electrolytes had the following compositions: $1 \cdot 10^{-2} \mathrm{M} \mathrm{NaOH}+5 \cdot 10^{-3} \mathrm{M}$ Gly, $1 \cdot 10^{-2} \mathrm{M} \mathrm{NaOH}+5 \cdot 10^{-3} \mathrm{M} \alpha$-Ala, and $1 \cdot 10^{-2} \mathrm{M} \mathrm{NaOH}+1 \cdot 10^{-2} \mathrm{M} \beta$-Ala. To solve the problem formulated in the present paper, $\mathrm{NaCl}$ was added to each background solution to obtain a wide range of concentrations (from $1 \cdot 10^{-6}$ to $1 \cdot 10^{-2} \mathrm{M}$ ). The working solutions were prepared in distilled water from chemically pure reagents. All the experiments were carried out in naturally aerated media at $20-22^{\circ} \mathrm{C}$.

The main investigation methods included inverse and cyclic voltammetry (IVA and CVA, respectively), chronoamperometry, and microscopy. Polarization experiments were conducted using a P-5827M potentiostat at a potential scan rate of $0.2 \mathrm{~V} \mathrm{~min}$ according to $^{-1}$ the standard method described in [5]. Monitoring of the copper surface before and after the experiments was performed using a MBS-2 $(\times 7)$ and a MIM-7 $(\times 500)$ microscopes. Additional studies were carried out using a JEOL 6380LV scanning electron microscope equipped with an EDS INCA 250 energy-dispersive unit to estimate the qualitative and quantitative composition of copper surface products.

Prior to each experiment, the electrode surface was polished with abrasive paper with gradually decreasing grain size, rinsed with ethanol and distilled water, and dried with filter paper. After immersion into the electrolyte, the electrode was cathodically prepolarized $(E=-1.00 \mathrm{~V} ; \tau=10 \mathrm{~min})$ and then its electrochemical behavior was studied by IVA or CVA methods in the potential range from -1.00 to $+0.80 \mathrm{~V}$.

The potentials of local activation $\left(E_{\mathrm{LA}}\right)$ and the induction period of local activation $\left(\tau_{\text {ind }}\right)$ were used as the main quantitative characteristics of copper local activation process under AA influence in background electrolytes and in the presence of AA anions simultaneously with $\mathrm{Cl}^{-}$ions [6]. 


\section{Results and discussion}

It has been found in previous studies $[5,7]$ that copper undergoes local activation (LA) in the background electrolytes at sufficiently high glycine and alanine concentrations $\left(5 \cdot 10^{-3}-\right.$ $\left.10^{-2} \mathrm{M}\right)$. In this case, the pits (PT) have the shape of spherical etch-pits and the number of pits is small $\left(2-3\right.$ on a working surface of $\left.7.85 \cdot 10^{-5} \mathrm{~m}^{2}\right)$ (Fig. 1a).

a)

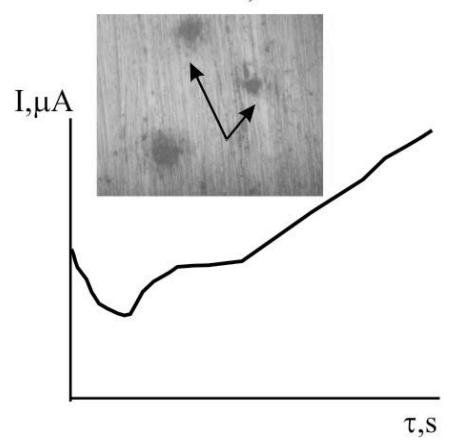

b)

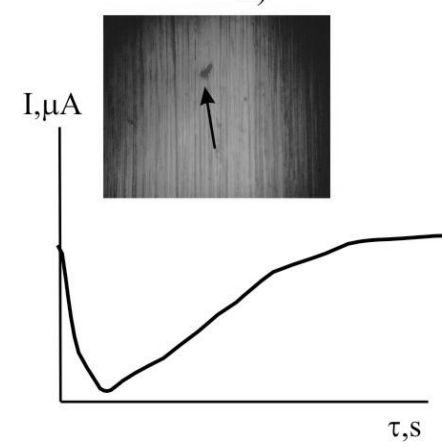

c)

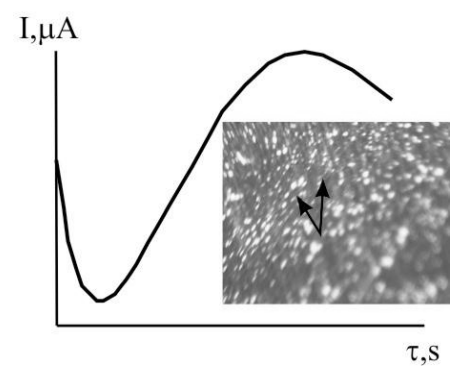

Fig. 1. Chronoamperograms and micrographs of copper surface $\left(\times 500\right.$, MIM-7) at $E_{\mathrm{LA}}, 1 \cdot 10^{-2} \mathrm{M}$ $\mathrm{NaOH}+5 \cdot 10^{-3}\left(1 \cdot 10^{-2}\right) \mathrm{M} \mathrm{AA}+X \mathrm{M} \mathrm{NaCl}: a, X=0 ; b, X=1 \cdot 10^{-5} ; c, X=1 \cdot 10^{-2}$.

For a more detailed study of the copper surface products formed under anodic oxidation conditions, scanning electron microscopy (SEM) and energy-dispersive analysis (EDX) were used. These methods allowed us to carry out elementary and quantitative analyses of the products. The results obtained showed that the metal surfaces after recording the anodic CVA fragment in $1 \cdot 10^{-2} \mathrm{M} \mathrm{NaOH}+5 \cdot 10^{-3} \mathrm{M}$ Gly $(\alpha$-Ala) solutions contained $\mathrm{O}(6 \mathrm{wt.} \%), \mathrm{Cu}(94 \mathrm{wt} \%$ ) and $\mathrm{O}(7 \mathrm{wt.} \%), \mathrm{Cu}(93 \mathrm{wt.} \%)$ in the systems with glycine and alanine, respectively. This suggests that the copper surface contains only oxygen-containing compounds of copper (probably, copper oxides). The absence of copper complexes with glycine and alanine on the metal surface confirms their high solubility. This conclusion correlates with literature thermodynamic [8] and kinetics [9] data.

Previously, the mechanism of copper local depassivation in the background electrolytes chosen above was examined in detail in [5,7] and was interpreted as dissociative type $\left(\mathrm{S}_{\mathrm{N} 1}\right)$ nucleophilic substitution of passivating particles by amino acid (AA) anions.

The main emphasis in the present investigation was made on estimating the character of $\mathrm{Cl}^{-}$ion effect on copper LA intensity in the chosen alkaline media containing AA anions as activators. The results obtained have shown that the observed effects differ significantly depending on the chloride ion concentration. Furthermore, a region of antagonism between an organic activator and small concentrations of the inorganic activator was observed in all the systems studied.

This effect was confirmed by electrochemical and physical methods. Upon addition of small concentrations of $\mathrm{NaCl}\left(1 \cdot 10^{-6}-1 \cdot 10^{-4} \mathrm{M}\right)$ to all background electrolytes (Figs. 2, 3, and 4), the CVA on copper changes its shape, the anodic current hysteresis loop on it vanishes, the $E_{\mathrm{LA}}$ values shift to a more positive region, and the $\tau_{\text {ind }}$ values increase. 


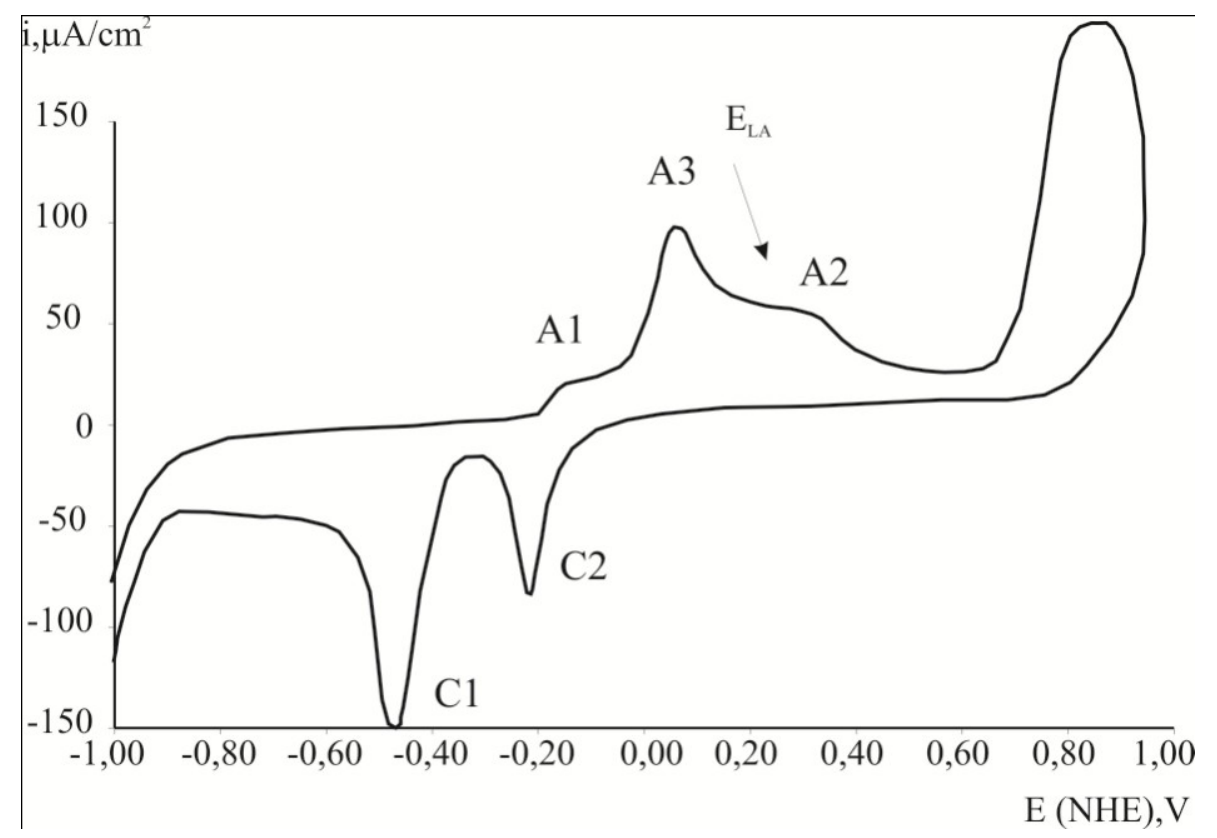

Fig. 2. CVA on copper at $1 \cdot 10^{-2} \mathrm{M} \mathrm{NaOH}+5 \cdot 10^{-3} \mathrm{M} \mathrm{Gly}+1 \cdot 10^{-5} \mathrm{M} \mathrm{NaCl}$, where $\mathrm{A} 1 / \mathrm{C} 1$ correspond to $\mathrm{Cu} / \mathrm{Cu}_{2} \mathrm{O}, \mathrm{A} 2 / \mathrm{C} 2$ correspond to $\mathrm{Cu}_{2} \mathrm{O} / \mathrm{CuO}, \mathrm{Cu}(\mathrm{OH})_{2}$, and $\mathrm{A} 3$ corresponds to $\mathrm{Cu}(\mathrm{Gly})^{+}, \mathrm{Cu}(\mathrm{Gly})_{2}$.

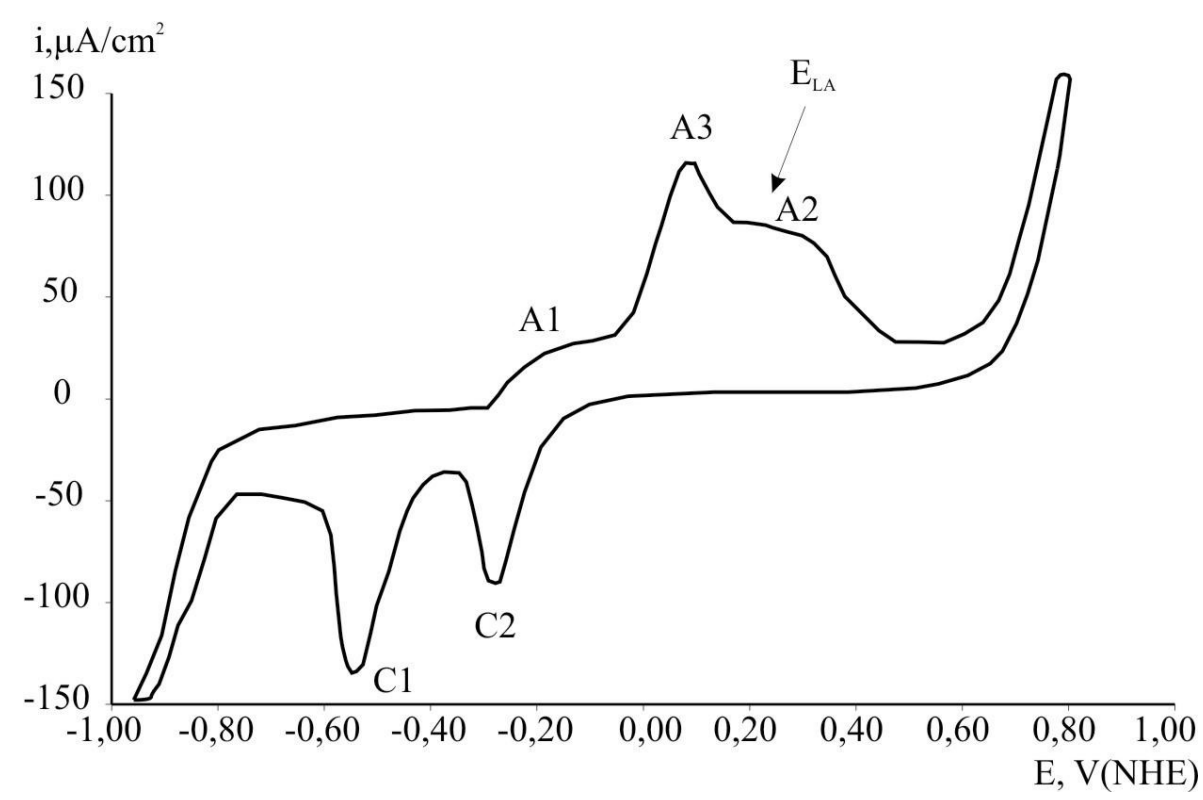

Fig. 3. CVA on copper at $1 \cdot 10^{-2} \mathrm{M} \mathrm{NaOH}+5 \cdot 10^{-3} \mathrm{M} \alpha$-Ala $+1 \cdot 10^{-5} \mathrm{M} \mathrm{NaCl}$, where $\mathrm{A} 1 / \mathrm{C} 1$ correspond to $\mathrm{Cu} / \mathrm{Cu}_{2} \mathrm{O}, \mathrm{A} 2 / \mathrm{C} 2$ correspond to $\mathrm{Cu}_{2} \mathrm{O} / \mathrm{CuO}, \mathrm{Cu}(\mathrm{OH})_{2}$, and $\mathrm{A} 3$ corresponds to $\mathrm{Cu}(\alpha-\mathrm{Ala})^{+}, \mathrm{Cu}(\alpha-\mathrm{Ala})_{2}$

Additional microscopic investigations have shown that after measuring the anodic IVA fragment on a metal electrode up to $E_{\mathrm{A}}=0.80 \mathrm{~V}$, the pits on the copper surface vanish in all the systems studied. On the other hand, local damage in the form of a few small pits (Fig. 1b) on an electrode are observed only after recording chronoamperometric curves at $E_{\mathrm{LA}}=0.350 \mathrm{~V}(\mathrm{Gly}), E_{\mathrm{LA}}=0.22 \mathrm{~V}(\alpha-\mathrm{Ala})$, and $E_{\mathrm{LA}}=0.64 \mathrm{~V}(\beta-\mathrm{Ala})$. This is probably 
because the LA process takes place rather slowly and cannot be detected during a CVA measurement (at a potential scan rate of $V=0.2 \mathrm{~V} \mathrm{~min}^{-1}$ ). On the other hand, competitive pit curing at $E_{\mathrm{A}}=0.50-0.80 \mathrm{~V}$ may not be ruled out [10].

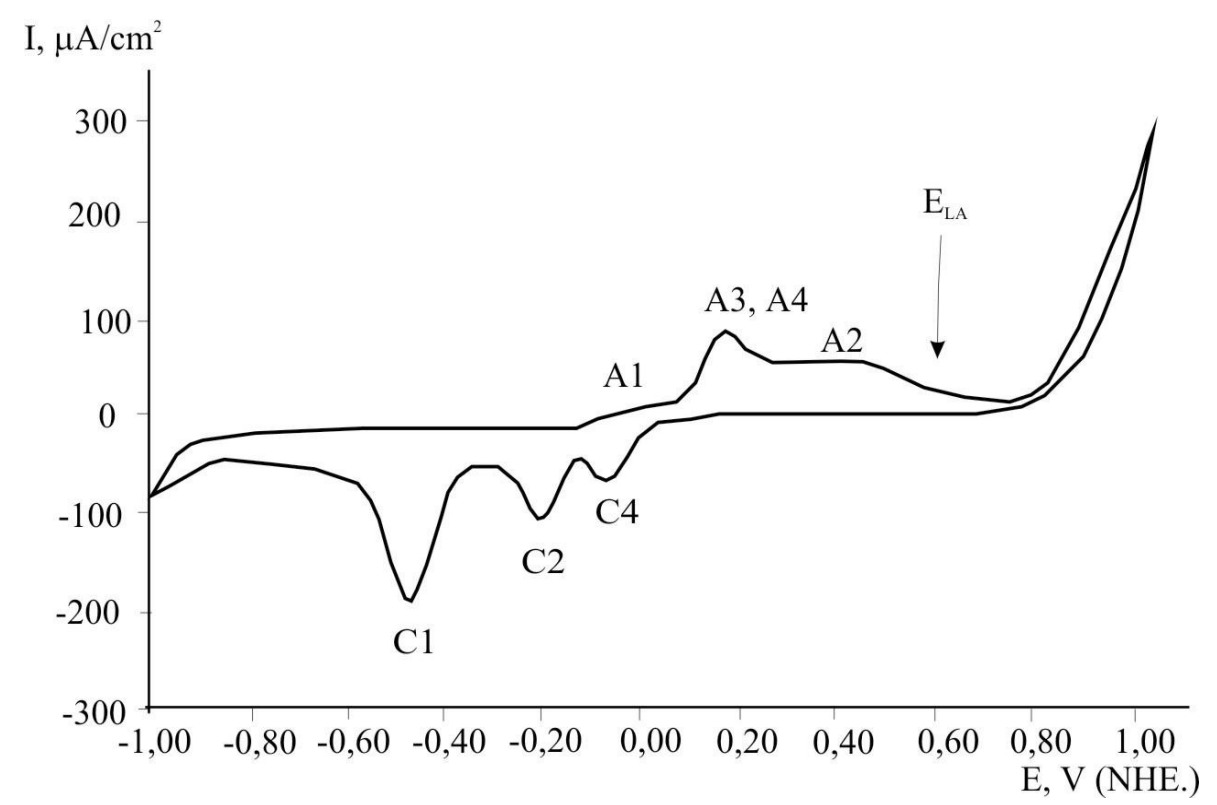

Fig. 4. CVA of copper at $1 \cdot 10^{-2} \mathrm{M} \mathrm{NaOH}+1 \cdot 10^{-2} \mathrm{M} \beta$-Ala $+1 \cdot 10^{-5} \mathrm{M} \mathrm{NaCl}$, where $\mathrm{A} 1 / \mathrm{C} 1$ correspond to $\mathrm{Cu} / \mathrm{Cu}_{2} \mathrm{O}, \mathrm{A} 2 / \mathrm{C} 2$ correspond to $\mathrm{Cu}_{2} \mathrm{O} / \mathrm{CuO}, \mathrm{Cu}(\mathrm{OH})_{2}, \mathrm{~A} 3$ corresponds to $\mathrm{Cu}(\beta$ $\mathrm{Ala})^{+}, \mathrm{Cu}(\beta-\mathrm{Ala})_{2}$, and $\mathrm{A} 4 / \mathrm{C} 4$ correspond to $\mathrm{Cu} / \mathrm{CuCl}$.

SEM/EDA analysis of the state of copper surface film in $1 \cdot 10^{-2} \mathrm{M} \mathrm{NaOH}+5 \cdot 10^{-3} \mathrm{M}$ Gly $+1 \cdot 10^{-5} \mathrm{M} \mathrm{NaCl}$, and $1 \cdot 10^{-2} \mathrm{M} \mathrm{NaOH}+5 \cdot 10^{-3} \mathrm{M} \alpha$-Ala $+1 \cdot 10^{-5} \mathrm{M} \mathrm{NaCl}$ solutions has shown that, after anodic polarization, $\mathrm{O}(5 \mathrm{wt} . \%), \mathrm{Cu}(91 \mathrm{wt.} \%), \mathrm{Cl}(4 \mathrm{wt} . \%)$, and $\mathrm{O}$ $(4 \mathrm{wt} . \%), \mathrm{Cu}(91$ wt. \%), $\mathrm{Cl}(5 \mathrm{wt} . \%)$ are found in the surface film in systems containing glycine and alanine, respectively. Comparison of the data obtained with the results recorded in the background electrolyte has shown that $\mathrm{Cl}$ appears on the metal surface whereas copper local damage is not observed. This fact may be due to the adsorption of $\mathrm{Cl}^{-}$ ions on the active sites of the copper electrode, followed by formation of a hardly soluble compound, copper monohalide $(\mathrm{CuCl})$. This substance prevents the subsequent adsorption of AA anions on the metal surface and formation of pits.

Transition to higher $\mathrm{NaCl}$ concentrations $\left(1 \cdot 10^{-3}-1 \cdot 10^{-1} \mathrm{M}\right)$ again causes a change in the CVA shape. In this case, the potentials of peaks A2 and A3 on their anodic parts shift to more positive potentials, and an additional peak (C4) appears at $-0.20 \mathrm{~V}$ in the cathodic CVA region $\left(E_{\mathrm{C}}=-0.20 \mathrm{~V}\right)$, which is related to reduction of hardly soluble copper monohalide $(\mathrm{CuCl})$ [8]. Simultaneously, anodic current hysteresis loops appear on the CVA again and pits are detected on the copper electrode surface. However, the damages differ significantly in character from those obtained earlier in the background solutions containing AA anions and have the form of numerous small shining pits. In this case, the $\mathrm{E}_{\mathrm{LA}}$ values of copper in systems with $C_{\mathrm{NaCl}}=1 \cdot 10^{-1} \mathrm{M}$ approach the values obtained in the 
background electrolytes and the shape of the chronoamperogram (Fig. 1c) becomes typical of the formation of hardly soluble compounds on a metal surface [11].

Studies by SEM/EDX methods have shown that $\mathrm{O}(10 \%), \mathrm{Cu}(83 \%), \mathrm{Cl}(7 \%)$, and $\mathrm{O}$ $(10 \%), \mathrm{Cu}(81 \%), \mathrm{Cl}(9 \%)$ are present in the copper surface film after anodic polarization in $1 \cdot 10^{-2} \mathrm{M} \mathrm{NaOH}+5 \cdot 10^{-3} \mathrm{M} \mathrm{Gly}+1 \cdot 10^{-2} \mathrm{M} \mathrm{NaCl}$, and $1 \cdot 10^{-2} \mathrm{M} \mathrm{NaOH}+5 \cdot 10^{-3} \mathrm{M} \alpha-$ Ala $+1 \cdot 10^{-2} \mathrm{M} \mathrm{NaCl}$ solutions, respectively, like in the systems with small $\mathrm{NaCl}$ concentrations. Thus, the elementary composition of copper surface products does not change in comparison with systems containing small $\mathrm{NaCl}$ concentrations, but the content of $\mathrm{Cl}$ and $\mathrm{O}$ increases and distinct pits appear on the metal surface.

The effects described above manifest themselves in the changes of the main quantitative characteristic of copper LA, $E_{\mathrm{LA}}$, under combined effect of Gly ( $\alpha$-Ala, $\beta$-Ala) and $\mathrm{Cl}^{-}$ions. In fact, in all the systems studied, in solutions with a constant organic activator concentration and the chloride ion concentration increasing in a wide range, the $E_{\mathrm{LA}}$ values for copper vary non-monotonously and are described by V-shaped curves (Fig. 5).

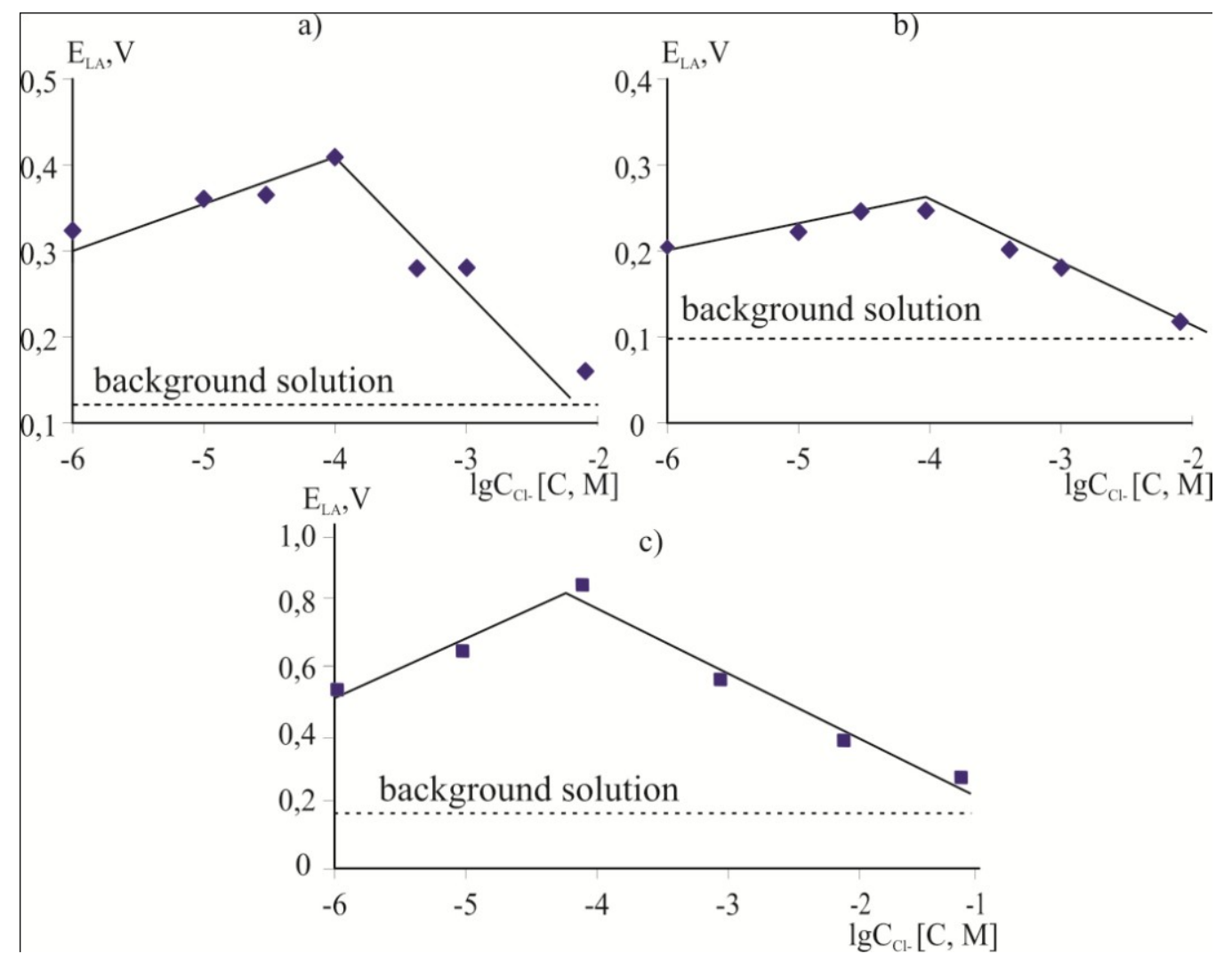

Fig. 5. Effect of $\mathrm{Cl}$ ion concentration on copper $E_{\mathrm{LA}}$ at: $(a) 1 \cdot 10^{-2} \mathrm{M} \mathrm{NaOH}+5 \cdot 10^{-3} \mathrm{M}$ Gly + $X \mathrm{M} \mathrm{NaCl},\left(\right.$ b) $1 \cdot 10^{-2} \mathrm{M} \mathrm{NaOH}+5 \cdot 10^{-3} \mathrm{M} \alpha$-Ala $+X \mathrm{M} \mathrm{NaCl},(c) 1 \cdot 10^{-2} \mathrm{M} \mathrm{NaOH}+1 \cdot 10^{-2} \mathrm{M}$ $\beta$-Ala, $X=1 \cdot 10^{-6}-1 \cdot 10^{-1}$.

These plots illustrate the "effect of antagonism of two activators" [2]. According to these plots, the copper resistance against LA in the $1 \cdot 10^{-6}-1 \cdot 10^{-4} \mathrm{M} \mathrm{NaCl}$ concentration range increases in all the systems studied in comparison with the background solution containing 
only AA anions. This effect is most pronounced at $C_{\mathrm{Cl}^{-}}=1 \cdot 10^{-4} \mathrm{M}$ (Fig. 5). A further increase in $\mathrm{NaCl}$ concentration results in a decrease in the "effect of antagonism of two activators" and $E_{\mathrm{LA}}$ shifts to more negative values to reach the value recorded in the background solution at $C_{\mathrm{Cl}^{-}}=1 \cdot 10^{-2} \mathrm{M}$ (Gly, $\alpha$-Ala) and at $C_{\mathrm{Cl}^{-}}=1 \cdot 10^{-1} \mathrm{M}$ ( $\beta$-Ala). However, the observed "effect of antagonism of two activators" is less pronounced in the system containing $\alpha$-Ala than in the other systems, which can be caused by the various complexing ability of the amino acids.

It is known [12] that Gly and $\alpha$-Ala form more stable complexes with copper $\left(\lg K\left(\mathrm{Cu}(\mathrm{Gly})_{2}\right)=15.38, \lg K\left(\mathrm{Cu}(\alpha-\mathrm{Ala})_{2}\right)=15.38\right)$ than $\beta$-Ala $\left(\lg K\left(\mathrm{Cu}(\beta-\mathrm{Ala})_{2}\right)=12.38\right)$. Thus at constant $\mathrm{pH}$ and concentrations of the ligand (AA) anions and copper ions, solutions with $\alpha$-Ala contain the greatest amount of complexes. This probably explains the higher $\alpha$-Ala activity and ability to form soluble complexes with copper ions even at small concentration [12].

The considerable suppression of copper LA upon addition of small $\mathrm{NaCl}$ amounts noted above may caused by two reasons. The first reason is related to the ability of $\mathrm{Cl}^{-}$ions (at low concentrations) to be adsorbed on the active sites of the copper electrode surface to form a hardly soluble compound, copper monohalide $(\mathrm{CuCl})$. The latter blocks the active sites and prevents the subsequent adsorption of AA anions. However, the critical concentration of $\mathrm{Cl}^{-}$ions necessary to form copper chloride complexes soluble in the electrolyte and causing LA is not reached.

The second reason, according to [13], may be related to the fact that small additives of $\mathrm{Cl}^{-}$ions can substitute water molecules and/or $\mathrm{OH}^{-}$ions in the adsorption complex thus making it more hydrophobic and hence less soluble in water and capable of slowing down copper anodic activation.

The decrease in the antagonism effect at $C_{\mathrm{Cl}^{-}}>1 \cdot 10^{-4} \mathrm{M}$ is due to the fact that inorganic anions themselves act as activators and stimulate the development of copper local damage as a result of complete displacement of AA anions from the adsorption complex.

\section{Conclusions}

Thus, systematic analysis of copper LA process in alkaline solutions containing AA (glycine, $\alpha$-, $\beta$-alanine) anions jointly with $\mathrm{Cl}$ ions $(\mathrm{NaCl})$ as an inorganic activator revealed the effect of "antagonism of two activators". This effect increases at small $\mathrm{NaCl}$ concentrations $\left(1 \cdot 10^{-6}-1 \cdot 10^{-4} \mathrm{M}\right)$ and decreases at $C_{\mathrm{Cl}^{-}}>1 \cdot 10^{-4} \mathrm{M}$. The results obtained were interpreted in terms of the copper local activation mechanism and complexation and adsorption differences between the organic and inorganic activators studied.

This study was supported by the Ministry of Education and Science of the Russian Federation (Project RNP 08-03-00194). 


\section{References}

1. A. Keenan, Ch. Webb, D. Kramer and K. Compton, J. Electrochem. Soc., 1976, 123, 179.

2. Yu. I. Kuznetsov and L.V. Frolova, Korroz.: mater., zashch., 2008, 4, 41 (in Russian).

3. Yu. I. Kuznetsov, Zashch. Met., 2002, 38, 122 (in Russian).

4. Yu. I. Kuznetsov, Usp. Khim., 2004, 73, 79 (in Russian).

5. E. A. Skrypnikova, S. A. Kaluzhina and E. V. Popova, Korroz.: mater., zashch., 2008, 11, 1 (in Russian).

6. L. I. Freiman, Itogi nauki $i$ tehniki: Korroziya $i$ zashchita ot korrozii (Advances in Science and Technology: Corrosion and Corrosion Protection), 1985, 4, 3 (in Russian).

7. S. A. Kaluzhina and E. V. Orlova, Praktika protivokorroz. zashch., 2002, 26, 11 (in Russian).

8. M. Pourbax, J. Electrochem. Soc. Reviews and News., 1976, 123, 25.

9. M. V. Rylkina, A. Yu. Chikanova, S. M. Reshetnikov and L. V. Trubacheva, Zahch. Met., 1999, 35, 27 (in Russian).

10. I. F. Abdulin, G. K. Budnikov, Y. N. Bakanina and N. N. Kukushkina, Zh. Anal. Khim., 1998, 53, 1075 (in Russian).

11. M. R. Gennero de Chialvo et al., Electrochim. Acta, 1985, 30, 1501.

12. Spravochnik khimika (Chemist's Handbook), ed. Acad. B.P. Nikol'sky, vol. 3, Leningrad, Khimiya, 1964 (in Russian).

13. Y.-Y. Su and M.Marek, J. Electrochem. Soc. 1994, 141, 940. 